\title{
DNA protective effect of rosmarinus officinalis total extract in mouse peripheral blood
}

\begin{abstract}
Rosmarinus officinalis is a common household aromatic plant widely used in cosmetic, food and folk medicine. The aim of this study was evaluated rosmarinus total extract (RTE) protective effect on DNA damage induced by cyclophosphamide (CP) and evidence the lack of genotoxicity and cytotoxicity of RTE in peripheral blood erythrocytes of Balb-C mice using the micronucleus assay. To evaluate the DNA protective effect, the dose of $100 \mathrm{mg} / \mathrm{kg}$ of RTE was used and given orally. Following was the admiration of $\mathrm{CP}(50 \mathrm{mg} / \mathrm{kg})$. To evaluated the lack genotoxic or cytotoxic, three doses $(30,100$ and $300 \mathrm{mg} / \mathrm{kg}$ ) of RTE were administered orally. A drop of blood was obtained from the tip of the tail of each mouse $24 \mathrm{~h}$ for six days. We found no increase of micronucleated erythrocytes (MNE) or micronucleated polychromatic erythrocytes (MNPCE). Nor did polychromatic erythrocytes (PCE) decline in mice treated with one of the three different doses of RTE. RTE extracts were capable of diminished DNA damage caused by CP thus reducing MNE and MNPCE frequencies. The lack of genotoxic and cytotoxic effect of the RTE and reduces the genotoxicity caused by $\mathrm{CP}$, suggest the potential therapeutic usefulness of this plant extract.
\end{abstract}

Keywords: genotoxicity, cytotoxicity, micronucleus, DNA protective effect, rosmarinus total extract
Volume 4 Issue 2 - 2018

\author{
Blanca Patricia Lazalde-Ramos,' Rosalinda \\ Gutiérrez-Hernández, ${ }^{2}$ Belinda Claudia \\ Gómez-Meda, ${ }^{3}$ Gabriela Morales Velazquez, ${ }^{4}$ \\ Claudia Araceli Reyes-Estrada, ${ }^{2}$ Sol María \\ Quirarte Báez, ${ }^{5}$ Yveth Marlene Ortiz- \\ García, ${ }^{4}$ Guillermo Moisés Zúñiga-González, ${ }^{6}$ \\ Ana Lourdes Zamora-Perez ${ }^{4}$ \\ 'Maestría en Ciencia y Tecnología Química, Universidad \\ Autónoma de Zacatecas, México \\ ${ }^{2}$ Unidad Académica de Medicina Humana, Universidad \\ Autónoma de Zacatecas, México \\ ${ }^{3}$ Instituto de Biología Molecular en Medicina y Terapia Génica, \\ Universidad de Guadalajara, México \\ ${ }^{4}$ Instituto de Investigación en Odontología, Universidad de \\ Guadalajara, México \\ ${ }^{5}$ Instituto Mexicano del Seguro Social, México \\ ${ }^{6}$ Laboratorio de Mutagénesis, Instituto Mexicano del Seguro \\ Social, México
}

\begin{abstract}
Correspondence: Ana Lourdes Zamora-Perez, Instituto de Investigación en Odontología, Centro Universitario de Ciencias de la Salud, Universidad de Guadalajara, José Maria Echauri y Juan Díaz Covarrubias s/n, Col. Independencia Guadalajara, Jalisco, C.P. 44340, México, Tel 01331058 5200, Email anazamora@gmail.com
\end{abstract}

Received: March 09, 2018 | Published: April 03, 2018

\section{Introduction}

The DNA molecule is one of the main targets of the attack of free radicals in the cell generating different types of oxidative damage. There is a wide variety of plants that contain antioxidants that can counteract the oxidative damage to DNA within which Rosmarinus officinalis (rosemary) is found. Rosemary is a common evergreen aromatic perennial herb belonging to family Lamiaceae and grows wild in most Mediterranean countries Erkan et al. ${ }^{1}$ Rosemary extract, especially aerial parts, are used as a flavoring and anti-oxidant agent in food and beverage and in cosmetic industry Medicherla et al., ${ }^{2,3}$ Rosemary is appreciated for its therapeutic in folk medicine uses for example as antidepressant, hepatoprotector, antidiabetic, antiangiogenic, anti-inflammatory and antitumor. ${ }^{4-8}$ Rosemary contains a complex mixture of phenolic antioxidants, including carnosol, carnosol acid and rosmarinic acid and are believed to be responsible for its pharmacological activity. ${ }^{9,10}$

The therapeutic properties attributed to plants are mainly responsible for the active principles it contains, and some poisoning and adverse reactions that can occur if used in inappropriate doses or for prolonged periods. Studies of medicinal plants in its preclinical phase include toxicology studies and within these are the genotoxicity tests. ${ }^{11-13}$ The in vivo micronucleus (MN) assay is a test used in screening genotoxicity and is recognized as part of product safety assessment. ${ }^{13}$ The MN are chromosomal fragments or whole chromosomes that spontaneously or because of clastogenic or aneuploidogenic agents, are excluded from the nucleus in mitosis. ${ }^{14}$ The MN formation leading to cell death, genomic instability, or cancer development. ${ }^{15}$ The mice peripheral blood MN assay is included in all testing batteries for genotoxicity and cytotoxicity safety evaluation and provides clear and accurate results Zúñiga-González et al., ${ }^{16}$ Zamora-Perez et al. ${ }^{17}$ In this work, we evaluated the protective effect of R. officinales total extract (RTE) on DNA damage induced by cyclophosphamide (CP) in peripheral blood erythrocytes of Balb-C mice using the in vivo $\mathrm{MN}$ assay. As well was evaluated the genotoxic and cytotoxic potential of RTE to guarantee its safe use in humans.

\section{Materials and methods}

\section{Plant material and preparation of the extract}

Dried leaves of R. officinales was obtained of Plantas Medicinales de América, S.A. de C.V. México, D.F., lot number 100210. The RTE was extracted as previously described..$^{5}$ The dry leaves were pulverized into fine powder, macerated in methanol and an extraction in a reflux system for $2 \mathrm{~h}$ at $62{ }^{\circ} \mathrm{C}$ was performed. The extraction was filtered under vacuum and was bleached with active carbon. A second 
extraction was performed to leaf residue with methanol and this extract was added to the first. The methanol extract was concentrated by distillation in a rotary evaporator. To this concentrated residue, distilled water was added which precipitated the RTE. Finally, the filtered precipitation was air-dried at room temperature to yield a fine yellow powder. ${ }^{18}$

\section{Animals}

All experiments were conducted with the approval of the local animal use regulatory body (Protocol register number UAZ-200835746) and carried out in full compliance with the guidelines for the care and use of experimental animals (Mexico; NOM-062-ZOO-2001) and international guidelines (Animal Welfare Assurance A5281-01). Thirty-five male Balb-C mice five to six weeks of age with average weight of $15.6 \pm 2.6 \mathrm{~g}$ were housed in a controlled environment with food and water ad libitum.

\section{Groups and test agent treatment}

Mice were distributed randomly into 7 groups of five animals each as shown in table 1 . All doses were administered orally daily for two and/or five consecutive days and were adjusted to a final volume of $0.1 \mathrm{~mL}$ per $10 \mathrm{~g}$ weight. To evaluate the genotoxic/cytotoxic effect of RTE, five groups were formed using the following scheme: Group one received sterile water; Group two received $50 \mathrm{mg} / \mathrm{kg}$ of CP (Sigma, St. Louis, MO; CAS No. 6055-19-2); Group three to five were given one of the three RTE doses (concentrations) $(30,100$, or $300 \mathrm{mg} / \mathrm{kg}$ bw., of RTE) (Table 1). The RTE doses were selected according as previously described Gutiérrez et al. ${ }^{5}$ To examine the effect of the RTE on DNA damage, a second experiment was performed as follows: Group six received $50 \mathrm{mg} / \mathrm{kg}$ of CP and $100 \mathrm{mg} / \mathrm{kg}$ of RTE separately (Table 1), and group seven was treated with $50 \mathrm{mg} / \mathrm{kg}$ of CP (Sigma, St. Louis, MO; CAS No. 6055-19-2) and 0.06mg/kg of folic acid (FA) GómezMeda et al., ${ }^{19}$ (Sigma, St. Louis, MO; CAS No. 59-30-3). Separately, both $\mathrm{CP}$ and FA were dissolved in water and all doses were adjusted to a final volume of $0.1 \mathrm{~mL}$ per $10 \mathrm{~g}$ weight.

Table I Experimental groups and treatment

\begin{tabular}{|c|c|c|c|c|}
\hline Treatment & $\mathbf{N}$ & Groups & Doses & $\begin{array}{l}\text { Exposure } \\
\text { Time }\end{array}$ \\
\hline Negative Control & 5 & I & Water & $\begin{array}{l}\text { Every } 24 \mathrm{~h} / 5 \\
\text { days }\end{array}$ \\
\hline $\mathrm{CP}$ & 5 & 2 & $50 \mathrm{mg} / \mathrm{kg}$ bw & $\begin{array}{l}\text { Divided into } \\
\text { two doses } \\
\text { every } 24 \mathrm{~h}\end{array}$ \\
\hline RTE 30 & 5 & 3 & $30 \mathrm{mg} / \mathrm{kg}$ bw & $\begin{array}{l}\text { Every } 24 \mathrm{~h} / 5 \\
\text { days }\end{array}$ \\
\hline RTE I00 & 5 & 4 & $100 \mathrm{mg} / \mathrm{kg}$ bw & $\begin{array}{l}\text { Every } 24 \mathrm{~h} / 5 \\
\text { days }\end{array}$ \\
\hline RTE 300 & 5 & 5 & $300 \mathrm{mg} / \mathrm{kg}$ bw & $\begin{array}{l}\text { Every } 24 \mathrm{~h} / 5 \\
\text { days }\end{array}$ \\
\hline RTE I00+CP & 5 & 6 & As in (4) and (2) & $\begin{array}{l}\text { Every } 24 \mathrm{~h} / 5 \\
\text { days + divided } \\
\text { into two doses }\end{array}$ \\
\hline $\mathrm{FA} 0.06+\mathrm{CP}$ & 5 & 7 & $\begin{array}{l}0.06 \mathrm{mg} / \mathrm{kg} \text { bw } \\
\text { and }(2)\end{array}$ & $\begin{array}{l}\text { Every } 24 \mathrm{~h} / 5 \\
\text { days + divided } \\
\text { into two doses }\end{array}$ \\
\hline
\end{tabular}

All doses were administered orally daily and were adjusted to a final volume of $0.1 \mathrm{~mL}$ per $10 \mathrm{~g}$ weigh. Rosemay total extract (RTE) in group 6 and folic acid (FA) in group 7 were administered two hours after cyclophosphamide (CP).

\section{Sample preparation and $\mathrm{MN}$ analysis}

A drop of peripheral blood was taken from the tip of the tail of each mouse immediately before the treatment ( $0 \mathrm{hr}$. or basal value) and $24,48,72,96$, and $120 \mathrm{hr}$ later. Two smears were made on cleaned microscope slides. The smears were air-dried, fixed in absolute ethanol for $10 \mathrm{~min}$, and stained with acridine orange (Sigma; CAS No. 10127023). ${ }^{20}$ All slides were coded before microscopic analysis. The $\mathrm{MN}$ in each sample was scored manually using a microscope equipped with epifluorescence and a 100X objective. The number of MNE in 10,000 total erythrocytes (TE: normochromatic and polychromatic erythrocytes) and the number of MNPCE in 1,000 PCE, and the proportion of PCEs in 1,000 TE were evaluated.

\section{Statistical analysis}

The animal was used as the experimental unit for the statistical tests. Results are expressed as the mean \pm standard deviation of MNE, MNPCE, and PCE frequencies. The data were evaluated using the Statistical Program for Social Sciences (SPSS, v11.0) for Windows medical pack (SPSS, Chicago, IL). After establishing the normal distribution of the data, a parametric test was performed. Comparisons were made between each treatment group and their respective basal value ( $0 \mathrm{hr}$.) by means of repeated measures one-way-ANOVA, followed by a Bonferroni test to correct the significance values of the multiple post hoc pairwise comparisons. A P-value of $<0.05$ was considered significant.

\section{Results}

\section{Evaluation of the genotoxic/cytotoxic effect of RTE}

The frequencies and comparison of MNE, MNPCE and PCE values in peripheral blood samples from mice treated with different doses of RTE are shown in Table 2. Comparisons showed that negative control and experimental groups at the three doses of RTE tested did not show a statistically significant difference in MNE, MNPCE or PCE frequency, during the sampling period. However, the dose of $100 \mathrm{mg} /$ $\mathrm{kg}$ of RTE presented significant decrease of MNPCE frequency from 48hours to 120 hours (Table 2). Moreover, the group who received the dose of CP (positive control) increased the frequency of MNE and MNPCE and decreased the proportion of PCE (Table 2).

\section{DNA protective effect of rosmarinus officinalis total extract}

Mice were treated with $\mathrm{CP}$ in the presence and the absence of $100 \mathrm{mg} / \mathrm{kg}$ of RTE or $0.06 \mathrm{mg} / \mathrm{kg}$ of FA during five days (Figure 1). The group who received RTE $100 \mathrm{mg} / \mathrm{kg}$ during five days simultaneously with $50 \mathrm{mg} / \mathrm{kg}$ dose of $\mathrm{CP}$ divided in two days showed a minor decrement of the proportion of PCE compared with the group who received $\mathrm{CP}$, this difference was significant at 48 hours of sampling $(\mathrm{P}=0.01)$. It was observed a significant decrease in the number of MNPCE $(\mathrm{P}=0.001)$ at 48 and 96 hours in the group who received RTE and $\mathrm{CP}$ compared with the group that received $\mathrm{CP}$ alone. In addition, this group presents a smaller increase in MNE frequency that the $\mathrm{CP}$ group. This difference was significant at 72 and 120 hours (Figure 1). In addition, the group receiving the dose of $\mathrm{CP}$ and $\mathrm{FA}$ presented a minor decrease in the proportion of $\mathrm{PCE}$ and a minor increase in $\mathrm{MNE}$ and MNPCE frequency in comparison to the group that receives CP (Figure 1). In relation to the proportion of PCE and MNE or MNPCE frequency, no statistical difference was found between the groups of $\mathrm{CP}+\mathrm{FA}$ and $\mathrm{CP}+\mathrm{RTE}$. 
Table 2 Absence of cytotoxic and genotoxic effect of three different doses the rosemary total extract in mice

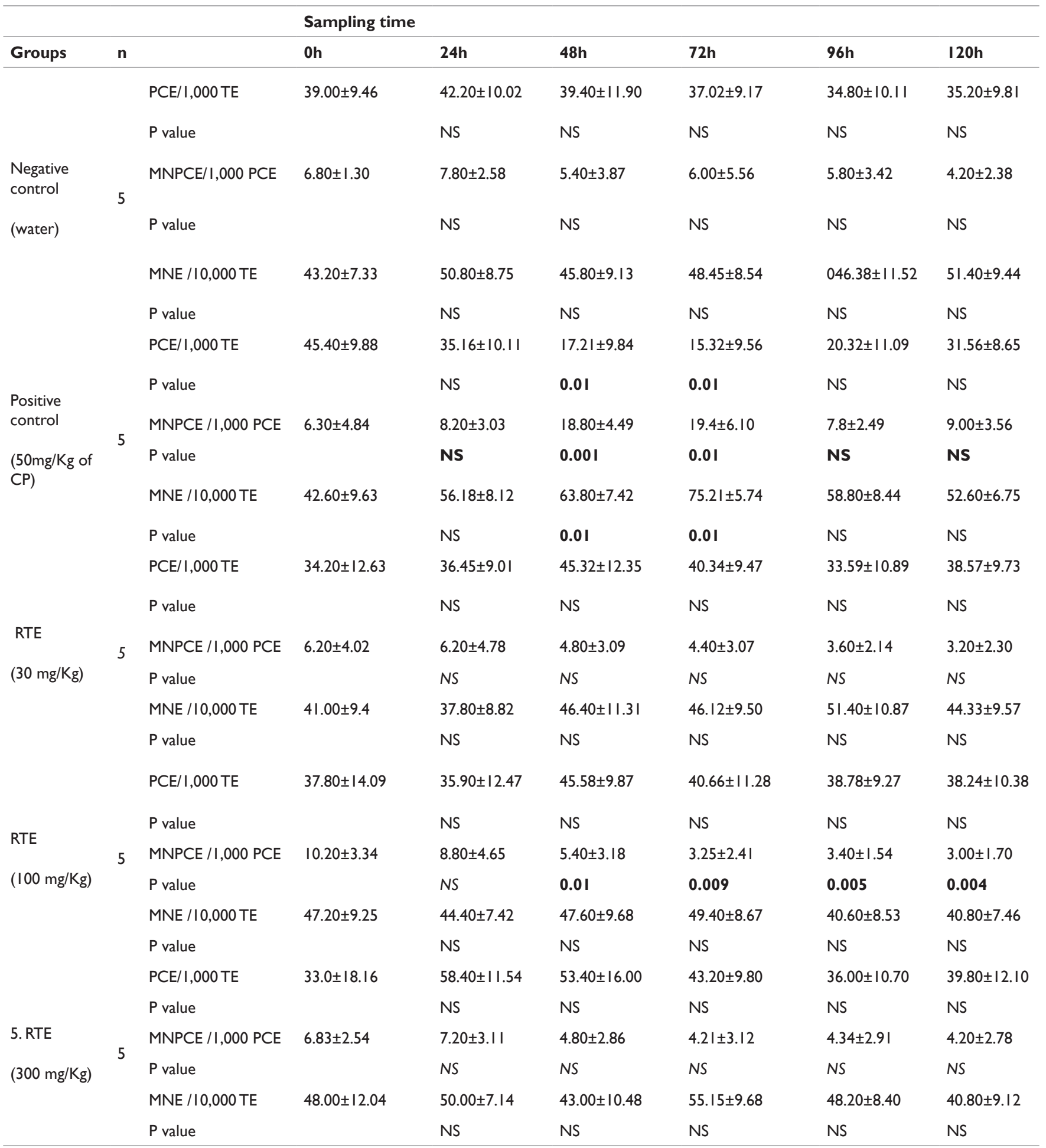

Data are expressed as mean \pm SD. Comparisons were made between different time points of the treatment groups and their respective basal values ( 0 hr). Abbreviations: NS, no significant; RTE, rosemary total extract; CP, cyclophosphamide; TE, total erythrocytes; PCE, polychromatic erythrocyte; MNPCE, micronucleated polychromatic erythrocytes; MNE, micronucleated erythrocytes. 


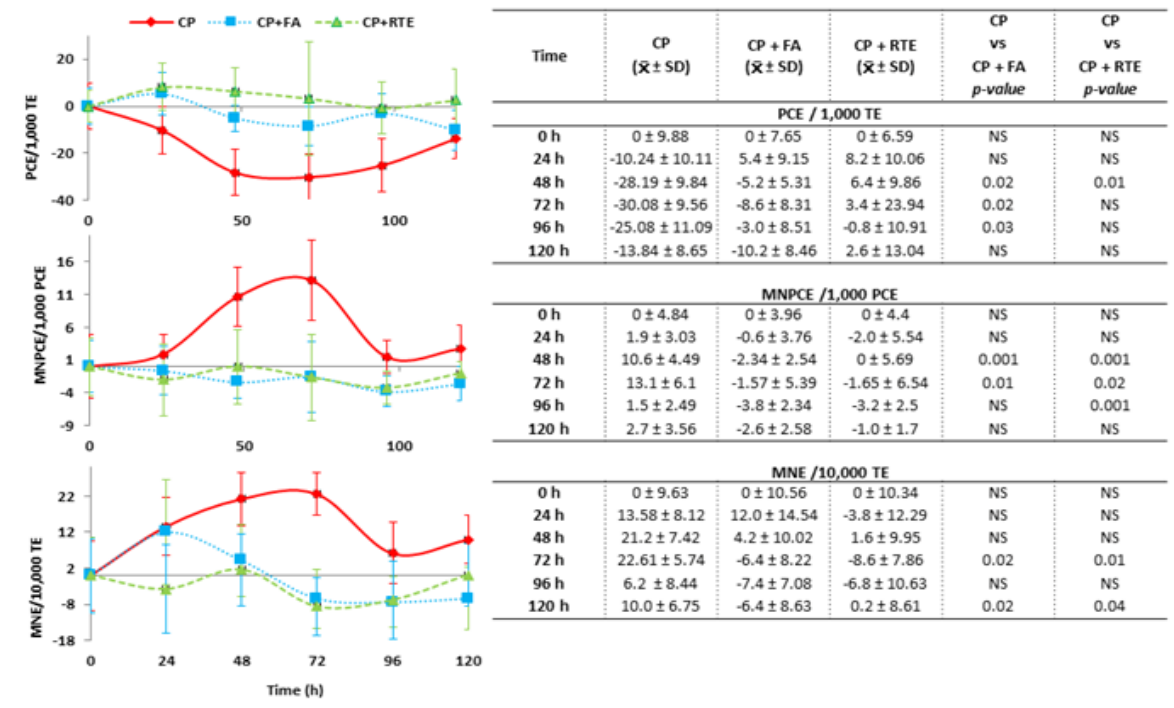

Figure I Proportion of micronucleated polychromatic erythrocytes (MNPCE), micronucleated erythrocytes (MNE) and polychromatic erythrocytes (PCE) in peripheral blood of mice treated with cyclophosphamide (CP) simultaneously with rosemary total extract (RTE) or folic acid (FA).TE, Total erythrocytes.

\section{Discussion}

This study was designed to investigate the protective effect of methanolic extract of Rosmarinus officinalis on induced DNA damage by a mutagenic as is the case of $\mathrm{CP}$, in vivo, also was evaluated the genotoxic and cytotoxic potential of RTE to ensure its safe use in humans. Genotoxicity and cytotoxicity of the different doses of RTE was measured using MN assay in mouse peripheral blood. Since peripheral blood is the first site of xenobiotics, it is biologically relevant to determinate DNA damage in this cellular type Larangeira et al. ${ }^{21} \mathrm{MN}$ is a cytogenetic assay based on counting $\mathrm{MN}$ in dividing cell population. It also demonstrated chromosomal damage and it is a marker of genomic damage Hayashi et al. ${ }^{15}$ Our results show that oral administration of different doses of RTE did not induced genotoxic or cytotoxic effect in mice peripheral blood. As it was expected, the group who received the dose of $\mathrm{CP}$ (positive control) increased the frequency of $\mathrm{MN}$ in normochromic and polychromatic erythrocytes and decreased the proportion of PCE (Table 2), thus demonstrating the validity of the experimental design. Our findings are in accordance with the study of Gaiani et al., ${ }^{22}$ who found that R. officinalis hydroalcoholic extract at doses of $6.43,100$ and $200 \mathrm{mg} / \mathrm{kg}$ body weight, did not induce statistically significant increases on MN frequency and MNPC frequency was increased but without significance. This differs from our results, since the three doses used in our study decreased MNPCE frequency, this could be explained, since it has been reported that RTE contains many substances like phenols with antioxidant and anti-lipoperoxidant activity Erkan et al., ${ }^{1}$ Wang et al. ${ }^{23}$ The literature mentions that the combination of two acid-phenols, leads to an increase in antioxidant efficacy activity. ${ }^{24}$ In addition, phenolic compounds may also indirectly act as antioxidants in cells by modulating the activity of antioxidant, detoxifying and repairing enzymes as well as enzymes involved in the bioactivation of xenobiotics Ferguson et al. ${ }^{25}$
On the other hand, some studies describe that rosemary extracts supplementation present potential positive health effects. Singletary and Nelshoppen, observed that dietary supplementation with rosemary extract with its individual antioxidative constituents resulted in a significant decrease in carcinogen DNA adduct formation in mammary epithelial formation Singletary \& Nelshoppen. ${ }^{26}$ In this study, the potential of RTE to reduce CP induced DNA damage was evaluated. As it shows in Figure 1, the dose of $100 \mathrm{mg} / \mathrm{kg}$ of RTE protect against the mutagenic effects of $\mathrm{CP}$. This decrease in $\mathrm{MN}$ demonstrated an antigenotoxic effect of RTE due to its antioxidant activity. ${ }^{1}$ Also our findings are according with those reported by different authors. Furtado et al. Furtado et al., ${ }^{27}$ reported the capacity of rosmarinic acid (natural phenolic compound of rosemary) to reduce the frequency of doxorubicin to induced MNPCE. Pereira et al. ${ }^{28}$ also found no DNA damage induced by rosmarinic acid in peripheral blood Wistar rat using the comet assay. Vattem et al., ${ }^{29}$ demonstrated the antimutagenic activity of rosmarinic acid in the Ames test using Salmonella typhimurium, in which rosmarinic acid inhibited the mutagenic potential of sodium azide and N Methyl-Nnitro-N-nitrosoguanidine and they concluded that the antimutagenic activity of rosmarinic acid might be due to modulation of the redox environment in the bacterial cell. Del Baño et al., ${ }^{30}$ reported that carnosic acid and carnosol are compounds with antimutagenic activity both before and after gamma-irradiation treatments. The inhibitory effect of rosmarinic acid was associated with the up regulation of superoxide dismutase and glutathione and its scavenging effect on free radicals Kin et al., ${ }^{31}$ Fahim FA et al., ${ }^{32}$ observed hepatoprotective and antimutagenic activities of the rosemary ethanolic extract and essential oil, respectively, and according with the authors, these effects are attributed to the presence of a relatively high percentage of phenolic compounds with high antioxidant activity. 


\section{Conclusion}

In conclusion, our results reveal that by means of $\mathrm{MN}$ assay in mouse peripheral blood erythrocytes, methanol extract of leaves of R. officinalis did not induce genotoxic or cytotoxic effect. By contrast, it shows DNA protective effect, to decrease DNA damage induced by cyclophosphamide and increasing the evidence about the antioxidant properties attributed to this plant. The absence of genotoxic and cytotoxic damage of RTE, as well as the antigenotoxic activity indicate the potential dietary and therapeutic safe usefulness of this extract.

\section{Acknowledgments}

None.

\section{Conflict of interests}

The authors declare no conflict of interest.

\section{References}

1. Erkan N, Ayranci G, Ayranci E. Antioxidant activities of rosemary (Rosmarinus Officinalis L.) extract, blackseed (Nigella sativa L.) essential oil, carnosic acid, rosmarinic acid and sesamol. Food Chemistry. 2008;10(1):76-82.

2. Medicherla K, Ketkar A, Sahu BD, et al. Rosmarinus officinalis L. extract ameliorates intestinal inflammation through MAPKs/NF- $\mathrm{\kappa B}$ signaling in a murine model of acute experimental colitis. Food Funct. 2016;13:32333243.

3. Ozarowski M, Mikolajczak PL, Bogacz A, et al. Rosmarinus officinalis L. leaf extract improves memory impairment and affects acetylcholinesterase and butyrylcholinesterase activities in rat brain. Fitoterapia. 2013;91:26171 .

4. Takeda H, Tsuji M, Inazu M, et al. Rosmarinic acid and caffeic acid produce antidepressive-like effect in the forced swimming test in mice. Eur J Pharmacol. 2002;449:261-267.

5. Gutiérrez R, Presno M, Serrano CJ, et al. Oxidative stress modulation by phytotherapy with Rosmarinus officinalis in CCl4-induced liver cirrhosis. Phytother Res. 2010;24:595-601.

6. Bakırel T, Bakırel U, Ustünerm KU, et al. In vivo assessment of antidiabetic and antioxidant activities of rosemary (Rosmarinus officinalis) in alloxandiabetic rabbits. J Ethnopharmacol. 2008;116:64-73.

7. Huang SS, Zheng RL. Rosmarinic acid inhibits angiogenesis and its mechanism of action in vitro. Cancer letters. 2006;239(2):271-80.

8. Manoharan S, Vasanthaselvan M, Silvan S, et al. Carnosic acid: a potent chemopreventive agent against oral carcinogenesis. Chemico-biological interactions. 2010;188(3):616-622.

9. Aruoma OI, Halliwell B, Aeschbach R, et al. Antioxidant and pro-oxidant properties of active rosemary constituents: carnosol and carnosic acid. Xenobiotica. 1992;22:257-68.

10. Zhang Y, Smuts JP, Dodbiba E, et al. Degradation study of carnosic acid, rosmarinic acid and rosemary extract (Rosmarinus officinalis L.) assessed using HPLC. J Agric Food Chem. 2012;60(3):9305-14.

11. Wall M, Wani M. Antimutagenic agents from natural products of terrestrial and marine origin. In: Antimutagenesis and anticarcinogenesis mechanisms, III Edited by G Bronzetti et al, Plenum press: New York; 1993: 87-97.

12. Linde K, Riet G, Hondras M, et al. Systematic reviews of complementary therapies an annotated bibliography. Part 2: Herbal medicinals. BMC complementary and alternative medicine. 2001;1:5.

13. Cassarett, Doull. Toxicología. 5th ed. McGraw Hill: USA; 1999: 254-417.
14. Schmid W. The micronucleus tests. Mutat Res. 1975;31:9-15.

15. Hayashi M, Tice RR, MacGregor JT, et al. In vivo rodent erythrocyte micronucleus assay. Mutation research. 1994;312(3):293-04.

16. Zúñiga-González GM, Torres-Bugarín O, Zamora-Perez A, et al. Induction of micronucleated erythrocytes in mouse peripheral blood after cutaneous application of 5-Fluorouracil. Archives of medical research. 2003;34(2):141-144.

17. Zamora-Perez AL, Lazalde-Ramos BP, Sosa-Macías MG, et al. Methylphenidate lacks genotoxic effects in mouse peripheral blood erythrocytes. Drug Chem Toxicol. 2011;34(3):294-99.

18. $\mathrm{Lu} \mathrm{AL}, \mathrm{Li} \mathrm{X}, \mathrm{Gu}$ Y, et al. Repair of oxidative DNA damage: mechanisms and functions. Cell Biochem Biophys. 2001;35(2):141-70.

19. Gómez-Meda BC, Zúñiga-González GM, Zamora-Perez A, et al. Folate supplementation of cyclophosphamide-treated mothers diminishes micronucleated erythrocytes in peripheral blood of newborn rats. Environ Mol Mutagen. 2004;44:174-78.

20. Zúñiga-González G, Gómez-Meda BC, Zamora-Perez A, et al. Induction of micronuclei in proestrus vaginal cells from colchicine- and cyclophosphamide-treated rats. Environmental and molecular mutagenesis. 2003;42(4):306-10.

21. Larangeira PM, de Rosso VV, da Silva VH, et al. Genotoxicity, mutagenicity and cytotoxicity of carotenoids extracted from ionic liquid in multiples organs of Wistar rats. Exp Toxicol Pathol. 2016;68(10):571-78.

22. Gaiani TF, Carvalho JCT, da Silva JMSF, et al. Absence of Clastogenic Effects of the Extract from Medicinal Plant Rosmarinus officinalis L. on Wistar Rat Bone Marrow Cells. Cytologia-Tokyo. 2006;71:101-106.

23. Wang W, Wu N, Zu YG, et al. Antioxidative activity of Rosmarinus officinalis L. essential oil compared to its main components. Food chemistry. 2008;108(3):1019-1022.

24. Cuvelier M, Richard H, Berset C, et al. Comparison of the antioxidative activity of some acid-phenols: structure-activity relationship. Bioscience, Biotechnology, and Biochemistry. 1992;56(2):324-325.

25. Ferguson LR, Philpott M, Karunasinghe N, et al. Dietary cancer and prevention using antimutagens. Toxicology 2004;198(4):147-159.

26. Singletary KW, Nelshoppen JM. Inhibition of 7,12-dimethylbenz[a] anthracene (DMBA)-induced mammary tumorigenesis and in vivo formation of mammary DMBA-DNA adducts by rosemary extract. Cancer letters. 1991;60(2):169-175.

27. Furtado MA, de Almeida LCF, Furtado RA, et al. Antimutagenicity of rosmarinic acid in Swiss mice evaluated by the micronucleus assay. Mutat Res. 2008;657(2):150-154.

28. Pereira P, Tysca D, Oliveira P, et al. Neurobehavioral and genotoxic aspects of rosmarinic acid. Pharmacol Res. 2005;52(3):199-203.

29. Vattem DA, Jang HD, Shetty K, et al. Synergism of cranberry phenolics with ellagic acid and rosmarinic acid for antimutagenic and DNA protection functions. Journal of food biochemistry. 2006;30(1):98-116.

30. Del Baño MJ, Castillo J, Benavente-García O, et al. Radioprotectiveantimutagenic effects of rosemary phenolics against chromosomal damager induced in human lyphocytes. J Agric Food Chem. 2006;54(6):2064-68.

31. Kim DS, Kim HR, Woo ER, et al. Inhibitory effects of rosmarinic acid on adriamycin-induced apoptosis in $\mathrm{H} 9 \mathrm{c} 2$ cardiac muscle cells by inhibiting reactive oxygen species and the activations of c-Jun Nterminal kinase and extracellular signal-regulated kinase. Biochem Pharmacol. 2005;70:106678.

32. Fahim FA, Esmat AY, Fadel HM, et al. Allied studies on the effect of Rosmarinus officinalis L. on experimental hepatotoxicity and mutagenesis. Int J Food Sci Nutr. 1999;50(6):413-427. 